World Lumen Congress 2021 | May 26-30, 2021 | Iasi, Romania

\title{
The Coronavirus Pandemic and Sustainable Development. Case Study: Romania
}

\author{
Ionela-Daniela GAITAN (BOTEZATU) \& \\ Gabriela PRELIPCEAN
}

https://doi.org/10.18662/wlc2021/24

How to cite: Gaitan (Botezatu), I.-D., \& Prelipcean, G. (2021). The Coronavirus Pandemic and Sustainable Development. Case Study: Romania. In A. Sandu (vol. ed.), Lumen Proceedings: Vol. 17 World Lumen Congress 2021 (pp. 228-240). Iasi, Romania: LUMEN Publishing House. https://doi.org/10.18662/wlc2021/24 


\title{
The Coronavirus Pandemic and Sustainable Development. Case Study: Romania
}

Ionela-Daniela GAITAN (BOTEZATU) ${ }^{1}$, Gabriela PRELIPCEAN²

\begin{abstract}
The coronavirus pandemic has affected all states in the world and the measures taken by governments to limit the spread of coronavirus have also left their mark on sustainable development goals, slowing their implementation or even regressing to some of these goals.

In the context in which the pandemic affected the Romanian economy and all segments of the population in all areas of the country, especially vulnerable groups, leading to an increase in existing disparities, the rapid implementation of sustainable development goals is the core of a sustainable and equitable recovery.

This paper presents effects of coronavirus pandemic on the sustainable development in Romania, especially on the objectives like no poverty, "zero" bunger, health and well-being, quality education, decent work and economic growth, industry, innovation and infrastructure and low inequalities, but also the solutions identified by various international bodies to reduce this impact.

Thus, the first part of the paper is a theoretical one, which presents the concept of "sustainable development" and analyses specialized studies that have presented the objectives of sustainable development, including studies that have shown the negative or positive effects of the coronavirus pandemic on these objectives.

The second part of the paper presents a descriptive analysis of the stage of sustainable development in Romania, after one year of coronavirus pandemic.

In carrying out this paper, qualitative research was used, based on methods such as descriptive analysis, analysis of official statistical data, study of reports and reference papers and synthesis of conclusions.
\end{abstract}

Keywords: sustainable development, objectives, coronavirus pandemic, effects, analysis.

\footnotetext{
${ }^{1}$ PhD., "Ştefan cel Mare" University, Suceava, Romania, ionela danielag@yahoo.com

2 Professor PhD, "Ştefan cel Mare" University, Suceava, Romania, gprelipcean@yahoo.com
} 


\section{Introduction}

The concept of sustainable development is increasingly used by various international bodies or in conferences. Although it is a concept encountered quite often before the year 2000 in developed countries, in Romania this concept took shape quite late, after Romania's accession to the European Union.

In 2008, Romania adopted the "National Strategy for Sustainable Development of Romania. Horizons 2013-2020-2030", which helped to recover from the financial crisis of 2008. This strategy, which aimed to meet certain objectives set in relation to the priorities and EU policies, but also with the global economy, have proved to have many shortcomings, not being in line with the new economic, social and environmental realities.

In 2018, the Romanian Government adopted the "National Strategy for Sustainable Development of Romania 2030", which involves the implementation of the 17 sustainable development objectives defined in the 2030 Agenda for sustainable development. This strategy emphasizes the importance of Romania's development on three dimensions: social, economic and environmental, being oriented towards the needs of the population.

Shortly after the adoption of this strategy in Romania, the country was affected by the coronavirus pandemic, which slowed down the implementation of sustainable development goals or even caused regressions of their implementation in some areas, especially affecting the vulnerable population. For this reason, efforts are being made in the next period to implement the sustainable development objectives by the proposed deadline, which will also result in a sustainable, equitable and resilient post-pandemic recovery.

\section{Conceptual approaches on sustainable development}

Various international meetings and conferences on environmental issues (climate change and environmental conservation) took place before the widespread use of the concept of sustainable development. Thus, in 1987, Brundtland Report (Our Common Future) was published by the WCED (World Commission on Environment and Development) regarding the development principles of the concept of sustainable development, in which this concept is defined, being the most used definition by researchers. 
Table 1. Definitions of the concept of sustainable development (SD)

\begin{tabular}{|c|c|c|}
\hline No. & Definitions & Source \\
\hline 1. & $\begin{array}{l}\text { SD is not a fixed state of harmony, but a process of } \\
\text { change in which the exploitation of resources, the } \\
\text { direction of investment, technological development } \\
\text { and institutional change are made in line with both } \\
\text { future and present needs. }\end{array}$ & $\begin{array}{l}\text { Brundtland } \\
\text { Report } \\
(1987)\end{array}$ \\
\hline 2. & $\begin{array}{l}\text { SD is a social construction derived from the long- } \\
\text { term evolution of an extremely complex system - the } \\
\text { human population and economic development - } \\
\text { integrated into the Earth's ecosystems and } \\
\text { biochemical processes. }\end{array}$ & $\begin{array}{c}\text { Meadows } \\
(1998)\end{array}$ \\
\hline 3. & $\begin{array}{l}\text { SD is a basic concept in the global development } \\
\text { policy and agenda, which provides a mechanism } \\
\text { through which society can interact with the } \\
\text { environment, while not risking harming the resource } \\
\text { for the future. }\end{array}$ & $\begin{array}{l}\text { Cerin } \\
(2006)\end{array}$ \\
\hline 4. & $\begin{array}{l}\mathrm{SD} \text { is a reconciliation of the economy and the } \\
\text { environment on a new path of development that will } \\
\text { allow a long-term development of humanity. }\end{array}$ & $\begin{array}{c}\text { Sterling } \\
(2010)\end{array}$ \\
\hline 5. & $\begin{array}{l}\text { SD refers to the principle of organization for } \\
\text { achieving human development goals, while } \\
\text { supporting the ability of systems to provide the } \\
\text { natural resources and ecosystem services on which } \\
\text { the economy and society depend. }\end{array}$ & $\begin{array}{l}\text { Evers } \\
(2018)\end{array}$ \\
\hline 6. & $\begin{array}{l}\text { SD is based on three concepts of: development } \\
\text { (socio-economic development in accordance with } \\
\text { environmental constraints), needs (redistribution of } \\
\text { resources to ensure quality of life for all) and future } \\
\text { generations (the possibility of long-term use of } \\
\text { resources for ensure the quality of life necessary for } \\
\text { future generations). }\end{array}$ & $\begin{array}{l}\text { Klarin } \\
(2018)\end{array}$ \\
\hline 7. & $\begin{array}{l}\text { SD represents the desire to achieve a balance, a } \\
\text { synthesis between the aspirations of the citizen born } \\
\text { free, the society on which it depends and through } \\
\text { which it is defined and the context that allows self- } \\
\text { realization. }\end{array}$ & $\begin{array}{l}\text { Romania's } \\
\text { national } \\
\text { strategy for } \\
\text { SD }(2020)\end{array}$ \\
\hline
\end{tabular}

Source: own elaboration according to the authors' definitions.

All definitions presented in the first table emphasize socio-economic development in relation to environmental conservation, redistribution of resources to increase the standard of living of the world's population and the use of long-term resources to ensure the livelihood of future generations. 
Over time, the concept of sustainable development has had 3 major periods. Thus, at the first United Nations (1973) conference in Stockholm in 1972, the concept of sustainable development was introduced for the first time, but this concept did not create a link between development and environmental issues. The post-conference report presented 28 principles to reduce poverty and conserve the environment. The second important period in updating the concept of sustainable development is marked by the establishment in 1983 of the United Nations World Commission on Environment and Development (WCED) which developed a program whose main objective was to highlight the negative effects of economic and social development on the environment. This commission also published the Brundtland Report in 1987, which defines the concept of sustainable development in the true sense. The third period, following the Brundtland Report, is marked by the 1992 Rio Conference (United Nations, 1992b), the preparation of which required the development of key documents in updating the concept of sustainable development, namely the "Rio Declaration on Environment and Development" and "Agenda 21".

The "Rio Declaration on Environment and Development" contains 27 principles of sustainable development, essential for balancing the environment with social and economic development. Thus, the population has the right to develop, but has the obligation to conserve the environment.

The "Agenda 21" program includes the objectives of sustainable development, but also the necessary resources and the action plan to be followed to achieve the objectives. This document, in addition to highlighting the importance of the balance between socio-economic development and environmental conservation, also emphasizes the need for international cooperation and the development of educational programs to ensure this balance.

The 2015 year was marked by the organization of the United Nations Summit for Sustainable Development in New York, which laid the foundations of the "Agenda 2030" program, which includes 17 sustainable development goals to be achieved by states until 2030 .

Romania, a member state of the United Nations and the European Union, joined, in 2018, the 17 Sustainable Development Goals of the 2030 Agenda, by adopting the "National Strategy for Sustainable Development of Romania 2030", whose elaboration was coordinated by the Department for Sustainable Development.

Thus, Romania has undertaken to implement the 17 objectives for sustainable development, presented in the "Agenda 2030", by 2030. The implementation of these objectives aims to ensure a better future for both the current population of the country and for future generations. These are: 
without poverty; "zero" hunger; health and well-being; quality education; gender equality; clean water and sanitation; clean and affordable energy; decent work and growth; industry, innovation and infrastructure; reduced inequalities; sustainable cities and communities; responsible consumption and production; climate action; aquatic life; terrestrial life; peace, justice and effective institutions and partnerships to achieve these goals.

Achieving these sustainable development goals by 2030 has been slowed by the emergence of the coronavirus pandemic, which has affected all states in the world. Until the pandemic, progress was made in implementing sustainable development goals, especially in low-income (poorly developed) countries.

The literature identified articles that addressed the effects of the coronavirus pandemic on sustainable development and the achievement of sustainable development goals by 2030 .

Thus, Khetrapal \& Bhatia (2020) and Thornton (2020) pointed out that the pandemic has slowed progress in the field of sustainable development, countries have focused more on global cooperation to reduce the negative effects of the pandemic, and the achievement of sustainable development goals by in 2030 being in the background.

According to the authors mentioned above, the most affected objective of sustainable development is the one related to health (objective 3), which is closely related to the objectives of poverty reduction, "zero" hunger, quality education, gender equality, clean water and sanitation, climate action, underwater life, land life and partnerships for goals. The authors emphasize the importance of financial investment which should be realized by government officials in health systems to reinvent and revitalize health systems, to make it easier to deal with new pandemics in the future, and to ensure access to the system and improve the quality of health systems.

Other authors, such as Gulseven, Al Harmoodi, Al Falasi and Al Shomali (2020), have shown that although the economic effects of the coronavirus pandemic have affected most sustainable development goals (negative health progress, job losses, school closures, the percentage of the population on the verge of poverty), measures to limit the spread of coronavirus such as air traffic closure have led to positive effects on the goal of reducing carbon emissions. Also, more responsible human consumption has led to a substantial reduction in waste.

Mee Kam Ng (2020) states in his paper that the implementation of sustainable development goals will help to deal more easily with a possible pandemic in the future. It presents the objectives of sustainable development that could be organized in 4 "P" (planet, people, prosperity and partnership). 
The first "P" (Planet) presented by the author refers to the fact that in order to achieve urban areas, more attention should be paid in the future to the effects that are produced on the environment. Urban areas should also consume fewer resources, be resistant to climate change and provide the population with access to nature (water and fresh air). Cities that also focus on the environment provide a healthier development environment for the population, thus managing to cope with new pandemics. The next "P" (People) emphasizes the goals of sustainable development as quality education, gender equality, without poverty and "zero" hunger, which implemented will reduce the vulnerable population, which in case of a pandemic requires additional help. Also, an educated population will know how to act in case of a pandemic, which is why it is necessary to study in schools the management of extreme risk events. The third "P" (Prosperity) refers to the responsibility of decision-makers on consumption and production, which no longer creates negative effects on the environment. Reducing the consumption of resources to achieve productions that meet market requirements requires innovation from decision makers. When the coronavirus pandemic broke out, capitalist development proved less effective. Thus, the economy being globalized, when measures were taken to stop the spread of coronavirus, there were situations in which some regions were more difficult to supply. This has drawn attention to the fact that it is necessary for each country to be able to meet its basic needs on its own in the event of extremely high-risk events.

At the same time, in order to better manage a pandemic, it is necessary to implement the fourth "P" (Partnership). The partnership is the solution to initiate changes for a sustainable economy and to better manage a future pandemic, to identify the pathogen much faster, in order to prevent its spread.

\section{Aims of the research and the methods used}

This article aims to identify the effects of the coronavirus pandemic on the implementation of sustainable development objectives in Romania. Thus, this article analyze the effects of the pandemic on the objectives: no poverty, "zero" hunger, health and well-being, quality education, decent work and economic growth, industry, innovation and infrastructure and low inequalities.

Qualitative research, based on methods such as comparative analysis, analysis of official statistical data, documentation of reports and specialized articles, was used to write this article. 


\section{Analysis of the effects of the coronavirus pandemic on the objectives of sustainable development in Romania}

The first goal of sustainable development, which is part of the 17 goals included in the "Agenda 2030" for sustainable development and adopted in Romania, is the goal "without poverty" (The Department Of Sustainable Development, 2020).

During the coronavirus pandemic, this goal, which aims to eradicate poverty and is closely linked to economic growth prospects, could not be achieved, as the pandemic caused a contraction of about $2 \%$ in global economic growth.

At European Union level, measures to manage the coronavirus pandemic have led to a decline in gross domestic product (GDP) of around 6,1\% in 2020 (European Court of Auditors, 2020, p. 7), causing job cuts and declines in tourism and imports and exports of goods and services. Also, people working abroad (migrants) were affected by temporary restrictions on international transport, as they were unable to go to work in another state.

At the level of the European Union, the evolution of the GDP rate in 2020 compared to 2019 shows us that Spain and Italy, the countries most affected in the EU in the first half of 2020 by the coronavirus pandemic recorded GDP decreases of 10,8\%, respectively $8,9 \%$. Romania registered a decrease in GDP in 2020 compared to the previous year of 3,9\%, being below the Union average.

These declines in GDP in the states of the European Union were mainly caused by the measures taken by governments to limit the spread of coronavirus, which were approached differently in each country, noting a lack of coordination at EU level in pandemic management in the first part of 2020.

Also, in 2020 it was observed the increase of the unemployment rate in Romania from 3.9\% in 2019 to 4.9, as a result of the significant impact of the coronavirus pandemic on the most vulnerable sectors in the country.

Globally, due to the pandemic, the extreme poverty rate has increased for the first time in the last 20 years, with approximately 120 million people falling into this category in 2020 (people living on less than RON 7.8 per day), this rate will increase to about 150 million people in 2021 .

This goal, which aims to eradicate poverty, is a difficult goal to achieve by 2030 , in the context of this extreme risk event - the coronavirus pandemic.

To help achieve this goal, the World Bank (2021) has proposed a number of solutions to reduce poverty, such as: closing the gaps between proposed policies and applying them in practice (the gap between what 
people live daily and political aspirations), constantly updating of data (much data on the new coronavirus are still unknown and innovative response systems are needed), investments in prevention and expanding cooperation and coordination.

Also, the GINI coefficient, which measures the level of inequalities in society, is estimated to increase in Romania, from the value of 34,8 in 2019 at the value of 35,1 in 2020 (Eurostat, 2021a).

Government representatives, responsible for Romania's economic recovery, tried to offer monetary stimulus packages. Over the next period, spending on health, education and social services could increase, which could have negative effects on the funds that could be allocated to activities to prepare for and prevent other high-risk events.

The implementation of the second goal of sustainable development, "zero" hunger, which aims to promote sustainable agriculture, reduce hunger and ensure food security, has been slowed by the measures taken by the authorities to reduce the effects of the new coronavirus.

The Global Hunger Index (Global hunger index, 2021) calculated for Romania for 2020 is less than $5 \%$, which means a low rate of the population suffering from hunger, but the pandemic has led to a slowdown in the decline of this index, being still at a great distance to reach the goal of "zero" famine by 2030 .

Romania has 13 million hectares of agricultural area, being the sixth country in the European Union as owned agricultural area, having a great potential for development in this field.

Measures to close the borders of European Union countries have led to the disruption of normal production flows and the inability of seasonal workers to harvest crops in some countries, which have led to temporary blockages for some types of food. The lack of labor in some states, which depended on workers from other states, has in some cases led to the bankruptcy of farmers and the loss of production.

In Romania, government representatives should pay more attention in the future to investments in the agricultural sector and create a functional framework for this sector to be maintained in the event of new crises caused by extreme risk events. All countries need a sustainable food production system to constantly provide basic food to the population.

The negative effect of the coronavirus pandemic on the third objective of sustainable development, health and well-being, which aims to ensure a healthy life and well-being of the population, is worrying, in Romania registering so far 1.060 .895 infected people with the new coronavirus, of which 28.616 people died (2,7\% of all infected people). 
In the field of health, Romania has faced a lack of medical supplies, necessary to deal with the crisis caused by the pandemic. For this reason, in the first half of 2020, the Romanian government has allocated in this area, funds of approximately 162.584 thousand euros.

In order to reduce the spread of the new coronavirus, during the state of emergency in Romania, telemedicine and digitalization of the health system were developed, and subsequently the vaccination of the population against Covid-19 was promoted.

A negative effect of the priority management of the Covid-19 crisis is that access to the medical system for people suffering from other diseases has taken a back seat, with measures restricting the movement of people limiting their access to the medical treatment they receive. In the first part of 2020, health systems around the world focused more on the population infected with the new coronavirus to the detriment of other medical problems that the population suffered from.

The fourth objective, quality education, aims to create learning opportunities for the entire population, throughout life. Quality education ensures sustainable development in all countries of the world, but the pandemic has made a significant impact in the countries most affected by the pandemic, as schools have been closed and many children in vulnerable groups have not had access to online media (especially those in rural areas and those in poor areas). The lack of quality education as a result of the pandemic affected the development of the skills of the population following a certain form of education.

During this pandemic period, the Romanian authorities invested in the online education system, by purchasing tablets for pupils and students and identifying/creating platforms for online courses.

At the beginning of the pandemic, about 185 countries worldwide closed their schools, including Romania, which is why working parents and central authorities had to find a solution for parents to take care of children. Thus, parents were given days off to look after their children, and if this was not possible, they were paid extra to cover the costs of a form of private education or to hire a person to look after them.

The objective of decent work and economic growth highlights the need to promote employment and productivity, but also sustainable economic growth.

The coronavirus pandemic came when the global economy was experiencing slow economic growth.

In 2019, global economic growth was 2,5\%, and in 2020, the coronavirus pandemic caused a decline in the global economy of about $5 \%$. 
Measures taken by the authorities in each country to stop the spread of coronavirus have also led to a decline in global economic activity. These measures include: closing non-essential areas of activity, disrupting supply chains, closing airspace, etc.

In Romania, the measures taken by the authorities to stop the coronavirus pandemic had negative consequences, namely: economic activity was severely affected because it was dependent on trade and investment in Western European countries, the automotive and tourism sectors ceased to function almost completely during the demand for transport services, staff, accommodation and food, which represents a relatively high share of total value added, collapsed, about $15 \%$ of employment contracts were suspended and $4 \%$ were finished during the emergency. Also, the loss of foreign investor confidence, resulting in a sharp deterioration in financial conditions. (OECD, 2020)

The negative effects of the coronavirus pandemic in Romania can be observed from the analysis of the main economic indicators in 2020 and the years before the coronavirus pandemic (table no. 2) (Eurostat, 2021).

Table 2. The evolution of the main economic indicators in Romania (\%)

\begin{tabular}{|c|c|c|c|c|c|}
\hline Economic indicator & $\begin{array}{c}2016 \\
\text { (current prices in } \\
\text { billions RON) }\end{array}$ & 2017 & 2018 & 2019 & 2020 \\
\hline GDP & 765,1 & 7,1 & 4,4 & 4,1 & $-3,9$ \\
\hline Private consumption & 478,2 & 10,0 & 7,3 & 5,9 & $-8,8$ \\
\hline Government consumption & 115,4 & 4,2 & 2,1 & 6,4 & 5,9 \\
\hline $\begin{array}{c}\text { Exports of goods and } \\
\text { services }\end{array}$ & 315,1 & 7,6 & 6,2 & 4,6 & $-13,1$ \\
\hline $\begin{array}{c}\text { Imports of goods and } \\
\text { services }\end{array}$ & 322,2 & 10,8 & 9,1 & 8,0 & $-10,6$ \\
\hline Unemployment rate & - & 4,9 & 4,2 & 3,9 & 4,9 \\
\hline
\end{tabular}

The import and export of goods and services in Romania registered in 2020 significant decreases, due to the traffic restrictions imposed by the authorities to manage the pandemic. Private consumption also suffered significant declines in 2020, mainly due to the population's tendency to save in times of crisis and job uncertainty.

In Romania, through the applied monetary policy, the central bank tried to support the population and the companies with loans, government 
bonds were purchased and the payment of credit rates for the companies and people affected by the pandemic was temporarily suspended.

Other solutions that can help rebuild the economy in the coming period are providing subsidies to low-income families, providing free advice to struggling companies or developing infrastructure to encourage investment in some affected areas.

The ninth objective, industry, innovation and infrastructure, is the key to achieving economic growth in each country, which generates new jobs and income.

In order to survive the crisis caused by the coronavirus pandemic in many areas of activity, it was necessary to use innovation, an essential element in the process of reinventing and continuing the activity, respecting the measures taken by the authorities. During this period it was observed that inequalities between people deepened more and more, so the closure of schools did not affect students in Finland in the same way, who are digitally advanced, compared to students in Romania, where it was necessary to make tablet purchases in schools and even to facilitate the access of some schools/ students to the internet.

Inequalities between people during the pandemic can be observed both intra-state (within states) and interstate (between states).

\section{Conclusion}

The effects of the coronavirus pandemic have not only appeared in the field of health, but have also extended to the economic, political or social field, influencing even the sustainable development objectives of the 2030 Agenda.

The most worrying are the effects of the coronavirus pandemic on the goals of poverty, unemployment, hunger and growth, with forecasts showing that the effects are more severe than those of the 2008-2009 financial crisis. Also, the coronavirus pandemic has put great pressure on the Romanian health systems, which have faced a lack of investment and workforce.

In order to effectively manage the coronavirus pandemic and limit the spread of the coronavirus, close cooperation between countries has proved necessary, as it is difficult for a single country to succeed in overcoming the pandemic crisis in this era of globalization. It is also necessary in each country to have cooperation between the public and private sectors, but also between the authorities and the population, in order to act in a coordinated way in the management of the coronavirus pandemic. 
The coronavirus pandemic has highlighted many of the problems that hinder the achievement of the goals set in the 2030 Agenda, which require new solutions to build the future society.

Government efforts to achieve sustainable development goals by 2030 could be the basis for a post-pandemic recovery.

\section{References}

Brundtland Commission. (1987). Brundtland Report (Report of the World Commission on Environment and Development: Our Common Future). https://sustainabledevelopment.un.org/content/documents/5987ourcommon-future.pdf

Cerin, P. (2006). Bringing economic opportunity into line with environmental influence: A discussion on the coase theorem and the Porter and van der Linde hypothesis, Journal Ecological Economics, 56, 209-225. https://doi.org/10.1016/j.ecolecon.2005.01.016

European Court of Auditors. (2020). Review No. 6 risks, challenges and opportunities in the EU economic policy response to the crisis caused by the COVID-19 pandemic. European Court of Auditors. https://www.eca.europa.eu/Lists/ECADocuments/RW20 06/RW Econ omic response to Covid19 EN.pdf

Eurostat. (2021a). Gini coefficient of equivalised disposable income - EU-SILC survey. Eurostat. https://appsso.eurostat.ec.europa.eu/nui/show.do? dataset $=$ ilc di12

Evers, B. A. (2018). Why adopt the Sustainable Development Goals? The case of multinationals in the Colombian coffee and extractive sector [Master Thesis]. Erasmus University Rotterdamus Repository.

Global Hunger Index. (2021). Global hunger index scores by 2021. GHI rank. https://www.globalhungerindex.org/ranking.html

Gulseven, O., Al Harmoodi, F., Al Falasi, M., \& Al Shomali, I. (2020). How the COVID-19 Pandemic Will Affect the UN Sustainable Development Goals?. SSRN. https://doi.org/10.2139/ssrn.3592933

Khetrapal, S., \& Bhatia, R. (2020). Impact of COVID-19 pandemic on health system \& Sustainable Development Goal 3. Indian J Med Res, 151(5), 395399. https://doi.org/10.4103/ijmr.IJMR 192020

Klarin, T. (2018). The Concept of Sustainable Development: From its Beginning to the Contemporary Issues. Zagreb International Review of Economics \& Business, 21(1), 67-94. https://doi.org/10.2478/zireb-2018-0005

Meadows, D.H. (1998). Indicators and Information Systems for Sustainable Development. A report to the Balaton Group 1998. The Sustainability Institute. https://edisciplinas.usp.br/pluginfile.php/106023/mod resource/ content/2/texto 6. pdf 
Mee Kam, Ng. (2020). Sustainable Development Goals (SDGs) and Pandemic Planning, Planning Theory \& Practice, 21(4), 507-512. https://doi.org/10.1080/14649357.2020.1807130

OECD. (2020). The World Economy on a tightrope. OECD. https://www.oecd.org/economic-outlook/june-2020/

Sterling, S. (2010). Learning for resilience, or the resilient learner? Towards a necessary reconciliation in a paradigm of sustainable education. Environmental Education Research, 16, 511-528. https://doi.org/10.1080/13504622.2010.505427

The Department Of Sustainable Development. (2020). Romania's national strategy for sustainable development. National Library of Romania. http://dezvoltaredurabila.gov.ro/web/wpcontent/uploads/2019/03/Romanias-Sustainable-Development-Strategy2030.pdf

The World Bank. (2021). Poverty. Worldbank.com. https://www.worldbank.org/en/topic/poverty/overview\#1

Thornton, J. (2020). Covid-19 pandemic has derailed progress on sustainable development goals, says WHO. BMJ, 369. https://doi.org/10.1136/bmj.m1969

United Nations. (1973). Report of the United Nations Conference on the Human Environment, Stockholm, 5-6 iunie 1972. United Nations Digital Library. https://digitallibrary.un.org/record/523249? ln=en

United Nations. (1992b). Rio Declaration on Environment and Development. In Report Of The United Nations Conference On Environment And Development. https://www.un.org/en/development/desa/population/migration/genera lassembly/docs/globalcompact/A CONF.151_26_Vol.I_Declaration.pdf 